\title{
Non infectious risk factors in pediatric sensorineural hearing loss
}

\author{
Bambang Udji Djoko Rianto, Bondan Herwindo, Ashadi Prasetyo, Anggoro Eka Raditya \\ Department of Otorhinolaryngology Head and Neck Surgery, Faculty of Medicine, \\ Universitas Gadjah Mada/Dr. Sadjito General Hospital Yogyakarta, Indonesia
}

DOI: http://dx.doi.org/10.19106/JMedSci004904201703

\begin{abstract}
Pediatric sensorineural hearing loss can cause delay in speech and daily social communication. The causative factors are infectious or non infecious. The role of infectious risk factors in pediatric sensorineral hearing loss has been proven. However, the role of non infectious factors has not been reported, yet. The aim of the study was to evaluate the role of non infectious factors in pediatric sensorineural hearing loss (SNHL). This was a case control study using data collected from outpatients and medical records in Dr. Sardjito General Hospital, Yogyakarta from June to December 2015. The inclusion criteria of case group were children with SNHL and aged $0-5$ years old, whereas the inclusion criteria of control group was children with normal hearing and aged 0-5 years old. The exclusion criteria were children with history of infectious risk factors and head trauma. Hearing status were determined by Otoacoustic Emission Testing (OAE) and Brainstem Evoked Response Auditory (BERA), based on $\alpha=5 \%, \beta=20 \%$; OR asumption $=3.0$. Sixty two subjects were selected with 31 subjects in each group. Multivariate analysis showed that low birth weight (LBW) ( $p=0.018 ;$ OR $=6.553 ; 95 \%$ $\mathrm{Cl}=1.38-31.13)$ and asphyxia $(p=0.041 ; \mathrm{OR}=6.448 ; 95 \% \mathrm{Cl}=1.077-38.595)$ were risk factors, while hyperbilirubinemia $(p=0.382 ; O R=2.46 ; 95 \% \mathrm{Cl}=0.365-$ 13.805) and gestation ( $p=0.876$; $O R=0.831 ; 95 \% \mathrm{Cl}=0.081-8.483$ ) were not risk factors for pediatric SNHL. In conclusion, LBW and asphyxia are risk factors for pediatric $\mathrm{SNHL}$, whereas prematurity and hyperbilirubinemia are not risk factors.
\end{abstract}

\section{ABSTRAK}

Tuli sensorineural pada anak dapat menyebabkan keterlambatan dalam berbicara dan komunikasi sosial sehari-hari. Faktor penyebabnya dibedakan atas faktor infeksi dan bukan infeksi. Peran faktor risiko infeksi pada gangguan pendengaran sensorik anak telah banyak dibuktikan, namun demikian peran faktor bukan infeksi belum banyak dilaporkan. Tujuan penelitian ini adalah untuk mengkaji peran faktor bukan infeksi terhadap tuli sensorineural pada anak. Penelitian ini menggunakan rancangan studi kasus kontrol dengan mengambil data dari pasien rawat jalan dan data rekam medis pasien di Rumah Sakit Umum Pusat Dr. Sardjito, Yogyakarta mulai bulan Juni sampai Desember 2015. Kriteria inklusi kelompok kasus adalah anak tuli sensorineural dan berusia 0-5 tahun. Kelompok kontrol adalah anak dengan pendengaran normal dan berusia 0-5 tahun. Kriteria eksklusi adalah anak dengan riwayat faktor risiko infeksi dan trauma kepala. Status pendengaran ditentukan oleh Otoacoustic Emission Testing (OAE) and Brainstem Evoked Response Auditory (BERA), berdasarkan $\alpha=5 \%, \beta=20 \%$; asumsi Rasio Odds: 3,0. Enam puluh dua subjek telah diseleksi dengan 31 subjek pada masing-masing kelompok. Hasil analisis multivariat

Corresponding author: djoriant@ugm.ac.id 
menunjukkan bahwa berat badan lahir rendah $(\mathrm{p}=0,018 ; \mathrm{OR}=6,553 ; 95 \% \mathrm{Cl}=1,38$ - 31,13$)$ and asphyxia $(p=0,041 ; O R=6,448 ; 95 \% \mathrm{Cl}=1,077-38,595)$ were risk factors, while hyperbilirubinemia $(p=0,382 ; O R=2,46 ; 95 \% \mathrm{Cl}=0,365-13,805)$ and gestation $(p=0,876 ; O R=0,831 ; 95 \% \mathrm{Cl}=0,081-8,483)$ bukan merupakan factor risiko. Dapat disimpulkan bahwa berat lahir rendah dan asfiksia merupakan faktor risiko tuli sensorineural pada anak, sedangkan prematuritas dan hiperbilirubinemia bukan sebagai faktor risiko.

Keywords: pediatric sensorineural hearing loss - risk factors - non infectious risk factors - low birth weight - asphyxia

\section{INTRODUCTION}

Hearing as one of the sensory functions, holds an important role in speech development which is the main component of social communication that depends mostly on hearing ability. Hearing loss is a common sensory deficits in the population, occurs in over 250 millions people worldwide. In 2005, World Health Organization (WHO) estimated, around 278 million people suffer from hearing loss, $75-140$ million of $t$ his number were found in South East Asia. A Multicenter Study conducted by WHO in 1998 found that Indonesia were in top 4 countries in South East Asia with rather high prevalency number of hearing loss (4.6\%), 3 other countries were Sri Lanka (8.8\%), Myanmar (8.4\%), and India $(6.3 \%){ }^{1}$

Congenital hearing loss is quite as serious issue in the field of otorhinolaringology especially because it is related to children's growth and development, which approximately happened to $1 / 1000$ newborn babies. The prevalency of congenital hearing loss in America was 1/1000 or around 0.1\%. The prevalency of healthy babies encountered with hearing loss in various degree are $3: 1000$, and the prevalence of babies with risk factors of hearing loss reached 6:1000. ${ }^{2,3}$ Children with hearing loss do not have the ability to hear sound within spectrum of 250 $\mathrm{Hz}-4 \mathrm{kHz}$. This hearing loss is causing speech and language delay. Based on etiology, sensorineural hearing loss in children is classified as two types, syndromic $(10-15 \%)$ and non-syndromic $(60 \%)$. Based on types of hearing loss, there are 4 types; conductive, sensorineural, mix, and central. ${ }^{4,5}$

The incidence of both severe and very severe sensorineural hearing loss (SNHL) is around 1:2000 in newborns, and 6:1000 in the age of 18 years old globally. This number indicated the occurence of SNHL, yet, this matter was not well responded and directed to suspicion in diagnosis. In example, unilateral severe and very severe hearing loss sometimes remains unknown until the children reach kindergarten age, most children were diagnosed after audiometry examination. Registry of children who had slightly high risk factors was designed for early screening in hearing ability. The results of examination in children with SNHL only discover $50 \%$ out of the high risk factor group, and the other $50 \%$ in those without risk factor. Therefore, this high risk group did not appreciate the occurence of SNHL. Many countries did not have any regulation about hearing loss screening in children and did not apprehend the risk factors so there are substantial number of undetected cases of hearing loss in children.,

Risk factors of SNHL in neonates based on Joint Commitee on Infant Hearing are 1) infectious risk factors: toxoplasmosis, rubella, 
cytomegalovirus, and herpes (TORCH) and 2) non-infectious risk: low birth weight (LBW) $(<1500$ grams), prematurity $(<34$ weeks gestation), asphyxia, hyperbulirubinemia, craniofacial anomalies, syndromes related to hearing damage and severe asphyxia after birth (APGAR $<7$ in 5 minutes after birth). Other non infectious risk factors are drug usage during pregnancy, pesistantly high lung pressure, intraventricular hemorrhage, high C-reactive protein $(\mathrm{CRP}) \geq 10 \mathrm{mg} / \mathrm{dL}$, although this last factor is not too influential.

Based on medical records in Dr. Sardjito General Hospital Yogyakarta during the year of 2011, there were 16 outpatient patients age $0-18$ years old, 13 outpatient patients age $0-5$ years old, 11 outpatient patients age $0-2$ years old, and 3 inpatient patients age $0-2$ years old diagnosed with SNHL (ICD10, code H90.5) and 127 outpatient patients age 0-2 years old, and 6 inpatient patients age 0-2 years old diagnosed with undetermied hearing loss (ICD10, code H 91.9). ${ }^{8-10}$

On examination of suspected hearing loss, many ways can be conducted such as Brainstem Evoked Response Auditory (ABR/ BERA), Steady-State Response Audit (ASSR), Otoacoustic Emission Testing (OAE). Gold standard on SNHL examination is Visual Reinforcement Audiometry (VRA), but this is difficult for infants under 6 months. Twenty four clicks-used in the BERA examination can provide an estimated hearing threshold at $1,000-4,000 \mathrm{~Hz}$. The OAE procedure is an examination option that can be performed for the benefit of screening for hearing loss because to know the results do not take long. ${ }^{8-13}$ This study was conducted to evaluate non infectious risk factors in pediatric SNHL in Dr. Sardjito General Hospital, Yogyakarta.

\section{MATERIALS AND METHODES}

\section{Study design}

This was an analytic observational study with case control design. The study begun with identification SNHL as an outcome in case group and patients with normal hearing function as a control group. Retrospectively observation was then performed to evaluate the existance of independent variables such as asphyxia, low birth weight, prematurity, and hyperbilirubinemia within both groups.

\section{Time and location}

The study took place in Department of Perinatology and Department of Otorhinolaryngology Head and Neck Surgery at Dr. Sardjito General Hospital Yogyakarta, which included routine physical ear nose, and throat exam, OAE, and BERA. The study was conducted from June to December 2015.

\section{Population and samples}

Study population consisted of children younger than 1 year old. A consecutive sampling was done to select the subject required for the study who met the inclusion and exclusion criterias. The case group consisted of children with SNHL, whereas the control group consisted of children without any hearing loss (normal hearing function). The exclusion criteria for both groups were subjects with TORCH infection or trauma during birth.

The sample size were calculated using sample size formulation for case control study or hypothesis testing for two proportion, with error type $I(\alpha) 5 \%$ two tailed hypothesis, error type II $(\beta) 20 \%$. The proportion of patients with SNHL were based on OAE and BERA with a few positive non-infectious risk factors observed was $17 \%$, the estimation of patients' proportion with normal hearing function 
with a few negative non infectious risk factor was $51 \%$, odd ratio 3.0 ; hence the minimum sample size needed for each group $(\mathrm{n} 1=\mathrm{n} 2)$ was 31 patients, with the total 62 patients. This study has been approved by the Medical and Health Research Ethics Committee, Faculty of Medicine, Universitas Gadjah Mada, Yogyakarta (Ref. KE/FK/65/EC).

\section{Statistical analysis}

Descriptive statistics were used to analyse the characteristics of subjects. Data were presented as frequency or percentage. The relationship between risk factors and SNHL was analysed using multivariate analysis. A p value $<0.05$ was considered significant.

\section{RESULTS}

The total subject of this study were 62 patients, consisted of 31 children with SNHL as the case group, and 31 children with normal hearing function as the control group. The distribution of variables neonatal asphyxia,body birthweght, gestation age and bilirubin serum are shown in TABLE 1.

TABLE 1. Distribution independent variable of samples in each group

\begin{tabular}{lcccc}
\hline \multicolumn{1}{c}{ Variable } & $\begin{array}{c}\text { Normal Hearing } \\
\text { Function }\end{array}$ & $\begin{array}{c}\text { Sensorineural hear- } \\
\text { ing loss (SNHL) }\end{array}$ & $\begin{array}{c}\text { OR } \\
(95 \% \mathrm{CI})\end{array}$ \\
\hline $\begin{array}{l}\text { Asphyxia [n (\%)] } \\
\quad \text { Normal }\end{array}$ & $22(70.9)$ & $11(35.5)$ & 4.44 & 0.01 \\
$\quad$ Neonatal asphyxia & $9(29.1)$ & $20(64.5)$ & $(1.35-15.08)$ & \\
$\begin{array}{l}\text { Birth weight [n (\%)] } \\
\quad \text { Normal }\end{array}$ & $21(67.7)$ & $11(35.5)$ & 3.82 & 0.01 \\
$\quad$ Low birth weight & $10(32.3)$ & $20(64.5)$ & $(1.18-12.67)$ & \\
Gestation [n (\%)] & $13(41.9)$ & $9(29.1)$ & 1.77 & 0.29 \\
$\quad$ Aterm & $18(58.1)$ & $22(70.9)$ & $(0.54-5.80$ & \\
$\quad$ Premature & & & & \\
Serum bilirubin [n (\%)] & $15(48.4)$ & $14(45.2)$ & 1.14 & 0.79 \\
$\quad$ Normal & $16(51.6)$ & $17(54.8)$ & $(0.37-3.49)$ & \\
$\quad$ Hyperbilirubinemia & & &
\end{tabular}

This study showed that the incidence of SNHL in neonatal asphyxia was significantly higher than in normal neonatal $(\mathrm{p}=0.01 ; \mathrm{OR}=$ $4.44 ; 95 \% \mathrm{CI}=1.35-15.08)$. The incidence of SNHL in LBW was also higher than in normal weight $(\mathrm{p}=0.01 ; \mathrm{OR}=3.82 ; 95 \% \mathrm{CI}=$ 1.18-12.67). No significantly different in the incidence of SNHL between born premature and born aterm $(\mathrm{p}=0.29 ; \mathrm{OR}=1.77 ; 95 \% \mathrm{CI}=$ $0.54-5.80$ ) and between hyperbilirubinemia and normal bilirubin $(\mathrm{p}=0.79 ; \mathrm{OR}=1.14$; 95\% CI $=0.37-3.49)$ (TABLE 1).

Further multivariate analysis showed that LBW ( $\mathrm{p}=0.018$; $\mathrm{OR}=6.553 ; 95 \% \mathrm{CI}=1.38$ $31.13)$ and asphyxia $(\mathrm{p}=0.041 ; \mathrm{OR}=6.448$; $95 \% \mathrm{CI}=1.077-38.595)$ were risk factors for pediatric SNHL, while hyperbilirubinemia $(\mathrm{p}=0.382 ; \mathrm{OR}=2.46 ; 95 \% \mathrm{CI}=0.365-13.805)$ and born premature $(\mathrm{p}=0.876 ; \mathrm{OR}=0.831$; $95 \% \mathrm{CI}=0.081-8.483$ ) were not risk factors (TABLE 2). 
TABLE 2. Multivariate analysis the relationship between risk factors and SNHL

\begin{tabular}{lcccc}
\hline Variables & $\beta$ & $\mathrm{p}$ & OR (Exp. $\beta)$ & $95 \%$ CI \\
\hline Low birth weight & 1.880 & 0.018 & 6.553 & $1.38-31.13$ \\
Neonatal asphyxia & 1.864 & 0.041 & 6.448 & $1.077-38.595$ \\
Bilirubin & 0.809 & 0.382 & 2.246 & $0.365-13.805$ \\
Premature & -0.186 & 0.876 & 0.831 & $0.081-8.483$ \\
\hline
\end{tabular}

\section{DISCUSSION}

Babies with LBW have higher risk factor in undergoing interference in development accompanied by speech and language delay, fine motor, adaptive, and personal social. Direct complication that can occur in LBW baby are hypothermia, hypogycemia, fluid and electrolyte disturbance, hyperbilirubinemia, respiratory distress syndrome, pantent ductus arteriosus, infection, intraventricular hemorrhage, apnea of prematurity, and anemia. Long term condition that may occur to LBW baby are developmental disorder, stunted growth, impaired vision (retinopathy), and hearing disorders. ${ }^{14,15}$

Sensorineural hearing loss remains a distinct cause of disability in surviving very preterm children and it is particularly associated with variables that indicate a severe respiratory course (duration of ventilation and oxygen treatment) despite there being no differences in birth weight, condition at birth, or initial disease severity. In terms of aetiology this fact is not helpful, as a longer respiratory illness may also be associated with greater exposure to risk factors, such as acidosis, antibiotic courses, and incubator or ventilator noise, and it is also associated with neurological injury. De Vries et al. ${ }^{14}$ found apnoeic spells more often in very LBW infants with SNHL than in unmatched LBW children.

Neonatal asphyxia or asphyxia in neonates is a spontaneous and irregular respiratory failure right after birth or a few moments after birth. Before birth, the fetal lungs doesn't work neither as an oxygen source or as a passage to release carbondioxide. Arteriolar vessels present in fetal lung are in a state of constriction causing low partial oxygen pressure $\left(\mathrm{PO}_{2}\right)$. Almost all of the blood from the right heart cannot pass through the lungs due to constriction of the fetal blood vessels, as a result, the blood flows through the vessels of lower pressure which is ductus arteriosus, then flows into the aorta. After birth, the baby will soon depend on the lungs as a primary source of oxygen. ${ }^{12}$

Recurrent hypoxia was important in the genesis of acquired SNHL. Three studies have identified ventilation and oxygen treatment with increased risk of hearing loss, although one study also included children with conductive losses. The aetiological pathway has not, however, been defined. The introduction of high frequency ventilation was initially associated with fears that noise induced losses may be produced, but this appears not to be the case. The association of high bilirubin levels with SNHL has its origins in the association between bilirubin encephalopathy and subsequent deafness. ${ }^{4}$

Hyperbilirubinemia can damage neurons and oligodendroglia by binding cell membranes which then damage mitochondria, inhibit oxidative phosphorylation, and cause calcium release to stimulate apoptosis. This will inhibit the growth of axonal or dendritic neurons. $^{8-10}$ 
In neonatal studies, bilirubin levels appear to cause delay in auditory brainstem response latencies, indicating changes in upper auditory pathways, which return to normal as bilirubin levels fall. The relation between high bilirubin levels and SNHL has been explored in several studies, all with slightly different methodologies. In LBW populations, associations have been observed between a range of hearing impairments at 8 years and high bilirubin levels, and between the maximum bilirubin concentration and SNHL. ${ }^{15}$

De Vries et al..$^{14}$ reported an interaction between birth weight, bilirubin concentration, and SNHL in a group of children $<34$ weeks' gestation with serum bilirubin levels $>240$ $\mu \mathrm{mol} / \mathrm{L}$. In this population study, there was little evidence of a direct relation between bilirubin and SNHL, no excess of children who triggered a $200 \mu \mathrm{mol} / \mathrm{L}$ threshold, or in those whose maximum bilirubin exceeded a notional exchange transfusion level equal to 10 times the gestational age in weeks. It was difficult to plot area under the bilirubin curve or to determine the maximum rate of increase with any accuracy because of poor recording of the time of sampling, which may have shed extra light on a possible relation.

Impaired hearing is prevalent in the world population. Intervening before the age of 6 months allows for normal development of language regardless of the degree of hearing loss. This condition may occur in neonates at or not at risk. The prevalence in low-risk neonates ranges from 0.09 to $2.3 \%$, in the high-risk population it ranges from 0.3 to $14.1 \%$. The prevalence of impaired hearing reaches $11 \%$ in very LBW neonates, however, included sensorineural, mixed and conduction hearing loss. Only $3 \%$ of these subjects were given individual hearing aids. A study that applied electrophysiology methods - evoked otoacoustic emissions - for analyzing neonates found a $6.3 \%$ rate of hearing impairment in very low birth weight infants. Another study that evaluated infants in neonatal intensive care units found prevalence rates of hearing loss ranging from 3 to $14.1 \%{ }^{4}$

This study described the prevalence of hearing loss and the features of children born in a tertiary reference hospital and monitored in an outpatient clinic for patients discharged from that hospital. The findings confirmed the $6.3 \%$ prevalence of hearing loss encountered previously in a survey of very LBW infants in Brazil using a similar method (DPOAE and BAEP testing). Other studies of very LBW infants presented lower prevalence values, such as $5.56 \%$ prevalence in 1998 , and $0.3 \%$ rate of sensorineural conditions in $2006 . .^{15,16}$

\section{CONCLUSION}

Variables of LBW and asphyxia were proved to be significant risk factors in SNHL in children. In contrast, prematurity and hyperbilirubinemia were not proved to be risk factors. Futher study is needed to determine the role of both infectious and non-infectious risk factors in the incidence of SNHL altogether to find out how much contribution from each risk factor in the event of SNHL in children.

\section{ACKNOLEDGMENTS}

We would like to thank all patients and their parents, also all research assistances (ENT Recidences and Nurses) who participated in this study. We would also like to thank Director of Dr. Sardjito General Hospital, Yogyakarta for the permission to perform this study.

\section{REFERENCES}

1. Iramawati D. Hubungan gangguan pendengaran dengan prestasi belajar siswa. 
[Karya Tulis Ilmiah]. Semarang: Fakultas Kedokteran Universitas Diponegoro, 2010.

2. Wrightson AS. Universal newborn hearing screening. Am Fam Physician 2007; 75(9):1349-52.

3. Gregg RB, Wiorek LS, Arvedson JC. Pediatric audiology in review. Pediatr Rev 2004; 25(7):224-34. http://dx.doi.org/10.1542/ pir.25-7-224

4. Billings KR, Kenna MA. Causes of pediatric sensorineural hearing loss: yesterday and today. Arch Otolaryngol Head Neck Surg 1999; 125(5):517-21. http://dx.doi. org/10.1001/archotol.125.5.517

5. Bielecki I, Horbulewicz A, Wolan T. Risk factors associated with hearing loss in infants: an analysis of 5282 referred neonates. Int J Pediatr Otorhinolaryngol 2011; 75(7):925-30. http://dx.doi.org/10.1016/j.ijporl.2011.04.007

6. Ohl C, Dornier L, Czajka C, Chobaut JC, Tavernier L. Newborn hearing screening on infants at risk. Int J Pediater Otorhinolaryngol 2009; 73(12):1691-5. http://dx.doi. org/10.1016/j.ijporl.2009.08.027

7. Carlson DL, Reeh HL. Pediatric Audiologi. In: Bailey BJ. Head \& Neck SurgeryOtorhinolaryngo-logy. $4^{\text {th }}$ ed. Philadelphia: Williams \& Wilkins; 2015.

8. Camilia RM, Cloherty JP. Neonatal hyperbilirubinemia. In: Cloherty JP et al. Manual of Neonatal Care. $5^{\text {th }}$ Ed. Lippincott Williams \& Wilkins, 2004; 185-221.

9. Madam A, Wong RJ, Stevenson DK, Clinical features and management of unconjugated hyperbilirubinemia in term and near term infants. http://store.utdol.com/app/index.asp. uptodate, Sept, 2004.

10. Agamanolis DP. Perinatal ischemia and stroke. Neuropathology: an illustrated interactive course for medical students and residents [serial online] 2017 July [cited 2017 August]. Available from : http://neuropathology-web. org/chapter3/ chapter3cPvl.html

11. Brad A. Audiologic evaluation of otologic/ neurotologic disease. In : Gulya AJ, Minor LB, Poe DS editors. Glasscock-Shambaugh's Surgery of the Ear . $6^{\text {th }}$ ed. Shelton : People's Medical Publishing House-USA, 2010: 15880.

12. Brookhouser PE. Sensorineural hearing loss. In: Bailey BJ, Johnson JT, Newlands SD editors. Head \& Neck SurgeryOtorhinolaryngology, $4^{\text {th }}$ ed. Philadelphia PA: Lippincott Williams \& Wilkins, 2006: 1289302.

13. Campbell KCM. Otoacoustic emissions. [serial online]. Mar 2016 [cited 2017 August]. Available from : http://emedicine.medsape. com/article/835943-overview

14. de Vries L, Lary S, Dubowitz LMS. Relationship of serum bilirubin levels to ototoxicity and deafness in high risk low birthweight infants. Pediatrics. 1985;76:351354.

15. Gill AW, Gosling D, Kelly C, Walker P, Wooderson S. Predischarge screening of very low birthweight infants by click evoked otoacoustic emissions. J Paediatr Child Health. 1998; 34:456-9. https://doi. org/10.1046/j.1440-1754.1998.00271.x

16. Roth AD, Hildesheimer M, Maayan-Metzger A, Muchmik C, Hamburger A, Mazkeret R. et al. Low prevalence of hearing impairment among very low birth weight infants as detected by universal neonatal hearing screening. Arch Dis Child Fetal Neonatal. 2006; 91(4):257-62. https://doi.org/10.1136/ adc. 2005.074476 